\section{Evaluation of Uranium in Organs of Residents from an Uranium-Rich Region using Teeth as Bioindicators}

\author{
João DT Arruda-Neto ${ }^{1 *}$, Fermin Garcia² and Henriette Righi ${ }^{1}$ \\ ${ }^{1}$ Department of Physics Institute, University of São Paulo, São Paulo-SP, Brazil \\ ${ }^{2}$ Department of Science and Technology, Santa Cruz State University, Ilhéus-BA, Brazil
}

\section{Abstract}

The Uranium extraction and processing plant of INB (Brazilian Nuclear Industries) is in Caetité, a city located in a region hosting the largest Uranium reserve of the country. The degree of Uranium contamination in the Caetité population was investigated before using teeth as bioindicator, where a quite high Uranium concentration was measured in this region, about 160 times higher than the world-wide average. Radiobiological risks are here evaluated from Uranium burdens in organs as skeleton, kidneys, liver, tissues and blood, which were estimated from transfer coefficients and effective internal doses. This was accomplished by means of calculations with the use of the STATFLUX/ICRP approach, plus a set of Uranium transfer rate parameters as function of individual's age assuming an uninterrupted exposure over a period of 60 years. It was found that $U$ ingestion rates by residents of Caetité are three orders of magnitude higher than worldwide average, indicating that food and water would exhibit high levels of contamination. Calculated effective internal doses range from a minimum of one to a maximum of three orders of magnitude higher than background doses, for blood and bones respectively. The likelihood that this circumstance could lead to serious health problems as e.g. neoplasia is addressed. The methodology presented in this work offers subsidies for further studies on environmental pollution by radionuclides.

\section{More Information}

*Address for Correspondence: João DT ArrudaNeto, Professor of Physics, Department of Physics Institute, University, University of Sao Paulo, Brazil Tel: +55 11 99464-4375;

Email: arruda@if.usp.br

Submitted: 30 January 2020

Approved: 21 March 2020

Published: 26 March 2020

How to cite this article: Arruda-Neto JDT, Garcia F, Righi H. Evaluation of Uranium in Organs of Residents from an Uranium-Rich Region using Teeth as Bioindicators. Int J Phys Res Appl. 2020; 3: 058-062.

DOI: 10.29328/journal.ijpra. 1001023

ORCiD: orcid.org/0000-0001-7827-1589

Copyright: @ 2020 Arruda-Neto JDT, et al. This is an open access article distributed under the Creative Commons Attribution License, which permits unrestricted use, distribution, and reproduction in any medium, provided the original work is properly cited.

Keywords: Teeth as bioindicator; Uranium contamination; Biokinetics model; Uranium burden in organs; transfer coefficients; Effective internal doses

Check for updates

OPEN ACCESS

\section{Introduction}

The Southwest region of the Bahia state in Brazil, encompassing the cities of Caetité, Igaporã and Lagoa Real, hosts the largest Uranium reserve of the country (100 kilotons only in uranium). The INB (Brazilian Nuclear Industries) extraction of Uranium and processing plant is located in Caetité (latitude $13^{\circ} 56^{\prime} 36^{\prime \prime} \mathrm{S}$ and longitude $42^{\circ} 15^{\prime} 32^{\prime \prime} \mathrm{W}$ ).

As pointed out elsewhere [1-4], wastes from the Caetite plant are categorized mostly as: (a) wastes from the mining operations which include waste rock and drainage waters, and (b) wastes from the industrial process, that is, leached ore and effluents from the milling plant. In fact, contamination of groundwater by the waste ponds is of great concern, where elevated levels of ${ }^{238} \mathrm{U}$ have been observed. This issue has been emphatically dealt with by the International Atomic Energy Agency, covering controllable releases to the environment in normal operation that may result from the mining and processing of ores for the extraction of uranium, and discharges of naturally occurring radioactive material [5]. Recommendations and guidance for performing prospective radiological impact assessments for facilities and activities were presented in IAEA 2018-b[6].

The risk of contamination of food (fruit, vegetables, meat, etc.) and drinking water must therefore be considered in the case of this uranium-rich region. Such a scenario motivated an investigation of Uranium concentrations in teeth of residents ( 5 to 87 years old) of this region, carried out at this Laboratory using a high-resolution inductively coupled plasma mass spectrometer (ICP-MS) [2]. The highest Uranium concentration in teeth was measured from samples belonging to residents of Caetité (median equal to $16 \mathrm{ppb}$ ). However, since Uranium concentrations in teeth and bones are similar, particularly for children and young adults, the Uranium body levels in residents of Caetite are, thus, quite high - actually, at least one order of magnitude higher than the worldwide average for bones [2]. Uranium concentrations in organs like bones and teeth are correlated with the amount of Uranium present in ingested food and water. In this regard, it is a matter of major concern the fact that Caetite has approximately 50,000 inhabitants, where half of them live in small farms, using non-treated water provided by wells and by a creek crossing the mining area. 
Teeth are good long-term (chronic) exposure monitors, working as reservoirs for many metals incorporated from the environment [3], and their metabolical similarity with bones, as pointed out above, allows the evaluation of contaminants accumulation in the skeleton [2].

Following uptake through the gastrointestinal tract, Uranium is mostly deposited in the skeleton. In fact, bone is one of the most important biological accumulators of Uranium [7]. As in the case of other metals such as $\mathrm{Cd}, \mathrm{Pb}, \mathrm{Si}$, Sr, etc., Uranium is also subject to stochastic processes of loss from circulation via excretion, redeposition in bone, or soft tissue uptake [8]. Although accounting for only a small fraction of the loss out of the circulation, soft tissues are quite relevant from a radiological viewpoint since they constitute several important organs.

Therefore, estimates of Uranium burdens also in organs other than teeth and bones are necessary for the evaluation of radiobiological risks to populations of the locality here examined, as well as from any other locality presenting radiological contamination.

Actually, Uranium as an alpha particle emitter is a source of ionizing radiation. Public concern, health risks from low-doses and biological responses could be found elsewhere [9].

In this sense, we presentestimates of Uranium accumulation in some important and/or vital organs (skeleton, kidneys, liver, tissues and blood) as function of time, obtained by means of a BIOKINETICS code developed at our Laboratory [4] using as input previously measured data for teeth [2].

\section{Materials and methods}

Calculations were performed with a code developed at our Laboratory, the STATFLUX code, which encompasses a statistical method for calculation of flow and set of parameters, supported by a Multiple Compartment Biokinetics Model [4]. It uses the Hamilton-Caley algebraic method [10] and the $4^{\text {th }}$ order Runge-Kutta numerical method [11], for mathematical solution of differential equation systems in the Uranium ICRP biokinetics model ICRP 69 [12]. This combined STATFLUX/ ICRP approach was validated at this Laboratory in a detailed case study dealing with the Uranium content in the diet of São Paulo City residents [13].

The accumulation of Uranium in skeleton, kidneys, liver, tissues and blood, was calculated with the use of the STATFLUX/ICRP approach and a set of Uranium transfer rate parameters as function of individuals age ICRP 69 [12], for an uninterrupted exposure over a period of 60 years. A key input, in this context, is the Uranium ingestion rates of residents from the studied city, which were estimated in the following way: (1) the concentration of $U$ in the skeleton was inferred from the corresponding data obtained for teeth [2], and (2) U ingestion rates were thus obtained as a free fitting parameter to these skeleton data (see Results).
Mathematical and procedure details involved in the calculations, as well as the calibration of the whole methodology, were developed at this Laboratory and published elsewhere $[4,13]$.

\section{Results and discussion}

\section{Biokinetics Model outcome}

Bone and teeth are nearly indistinguishable regarding metal incorporation (as e.g. lead and uranium). The younger the individual is, the greater is the similarity between teeth and bones. Moreover, cortical bone constitutes about $80 \%$ of the whole skeleton, and it is the bone structure presenting the highest similarity with teeth $[14,15]$. In this sense, and for the purposes of the present work, we consider the Uranium concentration in the skeleton of residents from the studied location (Caetité City) equal to the Uranium concentration in their teeth, as measured at this Laboratory as function of the individuals age [2] (Figure 1).

Two continuous curves for skeleton were generated by our STATFLUX/ICRP routine (see Material and Methods above) assuming Uranium ingestion rates (a free fitting parameter in the present approach) equal to $2 \mathrm{mg}-\mathrm{U} /$ day (curve- 1 in figure 1 ) and $12 \mathrm{mg}-\mathrm{U} /$ day (curve- 2 in figure 1 ), which provided the best set of curves encompassing the scattered data points for teeth. This wide amplitude of the $U$ ingestion rate is closely related to the heterogeneous dispersion of Uranium in the environment.

Actually, uranium worldwide average ingestion is 1 and $2 \mu \mathrm{g}-\mathrm{U} /$ day for food and water, respectively [13]. The fact that our estimates for $\mathrm{U}$ ingestion are nearly three orders of magnitude higher strongly suggests that contamination of food (fruit, vegetables, meat, etc.) and drinking water is a fact in this uranium-rich region (the circumstances were discussed in the Introduction).

The rationale of the present study is straightforward.

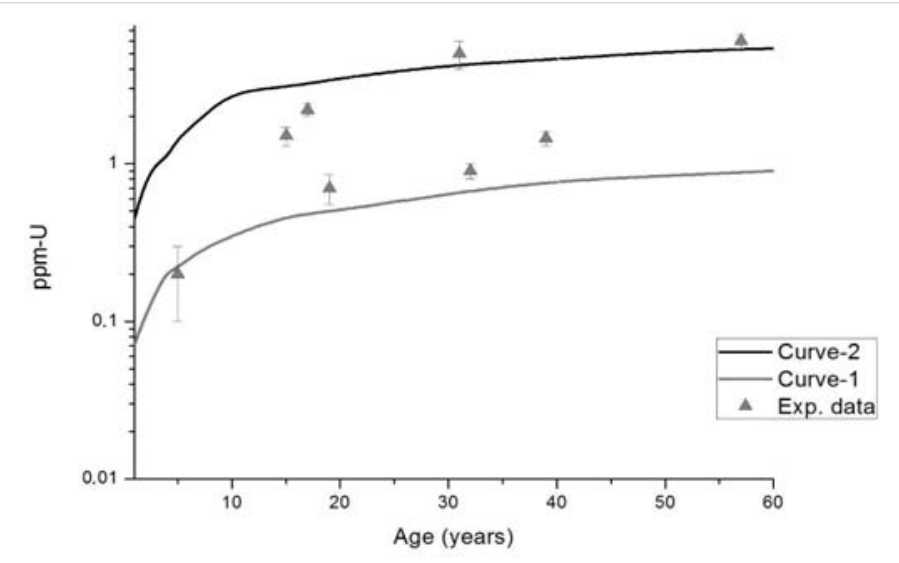

Figure 1: Data points: Uranium concentrations in teeth from residents of the studied location (Caetité city) as function of their age [2]. Continuous curves: outcomes of biokinetics model calculations for the skeleton (this work), where curve- 1 and curve- 2 were obtained assuming Uranium ingestion rates of $2 \mathrm{mg}-\mathrm{U} / \mathrm{d}$ and $12 \mathrm{mg}-\mathrm{U} / \mathrm{d}$, respectively. 
From experimentally obtained U concentration in teeth/bone, plus our STATFLUX/ICRP routine, it was possible infer that U ingestion rates of Caetité residents ranges, which ranges from $2 \mathrm{mg}-\mathrm{U} /$ day to $12 \mathrm{mg}-\mathrm{U} /$ day - this ingestion rate interval is by itself a quite important and concerning result. Next, by running the STATFLUX/ICRP routine and inputting this same $U$ ingestion rate interval at a chronic ingestion regime, we got estimates of Uranium concentrations in organs of great radiobiological relevance as function of the individuals age (Figure 2).

\section{Transfer coefficients}

In fact, food intake is one of the major routes for human exposure to environmental pollutants. This circumstance represents a significant contribution to the mean annual effective dose due to natural sources [16] Measurement of radionuclide concentrations present in foodstuff, intended for assessment of dose imparted by intake of feed products, was also previously performed at this Laboratory [13].

It is quite important, in this context, the obtaining of a radiobiological parameter which combines Uranium concentration, in a given organ, with the $U$ ingestion rate. In this regard, the so-called transfer coefficient $\left(T_{c}\right)$ measures the incorporation efficiency of a contaminant as a function of its daily intake (ingestion rate).

It is defined by

$$
T_{c}=C_{e} / A\left(\mathrm{~kg}^{-1} \cdot \mathrm{d}\right)
$$

where $C_{e}$ (mg-U/kg-organ) is, in the present study, the equilibrium concentration of Uranium in the organ after a prolonged, chronic daily ingestion, and $A\left(m g-U \cdot \mathrm{d}^{-1}\right)$ is the daily administered amount of Uranium [17].

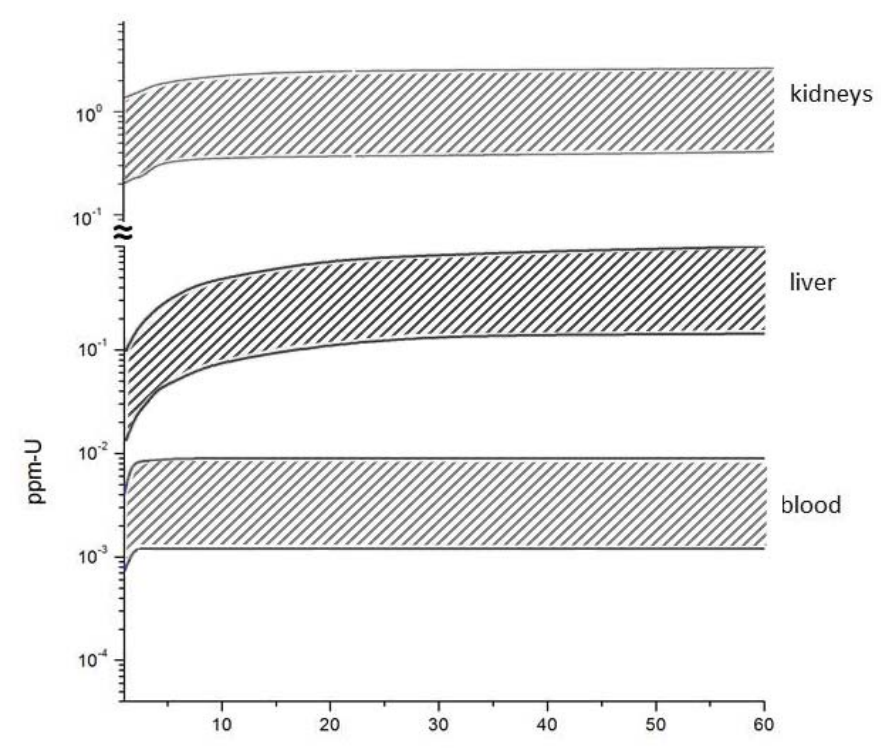

Figure 2: Outcomes from biokinetics model calculations (this work - see text for details) referring to Uranium concentrations in organs. The two curves delimiting the shaded bands correspond, as in Figure 1 , to Uranium ingestion rates of $2 \mathrm{mg}$ $\mathrm{U} / \mathrm{d}$ and $12 \mathrm{mg}-\mathrm{U} / \mathrm{d}$.
Taking into account the present results (Figure 1), it is reasonable to consider that the equilibrium concentrations $C_{e}$ are reached when the individual age is equal or over 60 years, which corresponds to the asymptotic outcome of the present STATFLUX/ICRP approach (curves in Figure 1). By entering these data in Eqn. 1 we obtained $T_{c}$ for skeleton (Table 1), kidneys, liver and blood (Table 2).

It is well established that $T_{c}$ is a decreasing function of A which saturates at high ingestion rates, while steeply increasing for much smaller A (see e.g. Figure 2 in ArrudaNeto et al., 2004-b) [18]. Quite consistently in this regard, $T_{c}=$ $4.7 \mathrm{~kg}^{-1} \cdot \mathrm{d}$ for $\mathrm{A}=0.7 \mathrm{mg}-\mathrm{U} / \mathrm{d}$ (worldwide average for humans), while is an order of magnitude smaller $\left(0.42 \mathrm{~kg}^{-1} \cdot d\right)$ for $\mathrm{A} \geq 2$ mg-U/d (present case study - Caetité) - Table 1. In this sense, the fact that

$$
T_{c}(\mathrm{~A}=2 \mathrm{mg}-\mathrm{U} / \mathrm{d}) \approx T_{c}(\mathrm{~A}=12 \mathrm{mg}-\mathrm{U} / \mathrm{d})
$$

within calculation uncertainties, is additional indication that Uranium ingestion rates by Caetité residents are quite high. This $T_{c}$ saturation was also observed for the kidneys simulation. Transfer coefficients for kidneys, liver and blood are presented in table 2. While $T_{c}$ for kidneys is of the same order of those for bones (Table 1), for blood they are quite small (this issue is retaken in paragraph 3.3.3).

Additionally, the Uranium $T_{c}$ for bones of the residents of Caetité compares well with those obtained with Beagle dogs [19]. In fact, earlier results suggest that the Beagle may be an appropriate experimental animal from which we can extrapolate data to humans with reference to the percentage of $\mathrm{U}, \mathrm{Th}$, and $\mathrm{Pu}$ found in their organs [20].

\section{Burden in the organs}

Radiological impacts and risk of radiation effects in humans and populations were recently updated by the International Atomic Energy Agency [6]. In this regard, radiological burdens related to Uranium could be evaluated from its concentrations in the organs, while estimates of effective doses allows

\begin{tabular}{|c|c|c|c|c|c|c|}
\hline$A(-U / d)$ & 0.7 & 2 & 5 & 12 & 60 & References \\
\hline Caetité & --- & $0.35 \pm 0.10$ & --- & $0.42 \pm 0.10$ & --- & this work \\
\hline $\begin{array}{l}\text { Worldwide } \\
\text { average }\end{array}$ & 4.7 & --- & -- & --- & -- & $\begin{array}{l}\text { Fermin. et al. } \\
2006 \text { (Table 3) }\end{array}$ \\
\hline Wistar rats & --- & $0.6 \pm 0.1$ & $0.2 \pm 0.05$ & --- & --- & $\begin{array}{l}\text { Arruda-Neto, et } \\
\text { al. 2004-b }\end{array}$ \\
\hline $\begin{array}{l}\text { Beagle } \\
\text { dogs }\end{array}$ & --- & --- & - & $0.31 \pm 0.08$ & $0.14 \pm 0.05$ & $\begin{array}{l}\text { Arruda-Neto et } \\
\text { al. 2004-a }\end{array}$ \\
\hline
\end{tabular}
assessments on impacts and risk as outlined below.

Table 2: Transfer Coefficients $\left(\mathrm{kg}^{-1} \cdot \mathrm{d}\right)$ - this work.

\begin{tabular}{|c|c|c|}
\hline & \multicolumn{2}{|c|}{ A (mg-U/d) } \\
\hline & 2 & 12 \\
\hline kidneys & $0.21 \pm 0.04$ & $0.18 \pm 0.03$ \\
\hline liver & $0.08 \pm 0.03$ & $0.8 \pm 0.2$ \\
\hline blood & $(8 \pm 2) \times 10^{-4}$ & $(6 \pm 2) \times 10^{-4}$ \\
\hline
\end{tabular}


As detailed calculated elsewhere [18], the average dose imparted by Uranium to a target tissue, only by its emitted alpha particles, is (see eqn. 19 in Arruda-Neto, et al. 2004-b) [18].

$$
\mathrm{D}_{\alpha}=3.17 \times 10^{-8} \times \mathrm{M}_{\mathrm{U}}(\mathrm{mg}) \times \Delta \mathrm{t}(\mathrm{s}) \text { (Gy - Gray) }
$$

where $\mathrm{M}_{\mathrm{U}}$ is the Uranium mass embedded in the tissue and $\Delta t$ is the exposure time.

The effective dose from alpha particles in one kilogram of soft tissue for one year of exposure is (see eqns. 20 and 21 in Arruda-Neto, et al. 2004-b) [18]

$$
\mathrm{E}_{\alpha}=4.2 \times \mathrm{ppm}(\mathrm{U})(\mathrm{Sv} /(\mathrm{y} \cdot \mathrm{kg}) \text { - Sievert per year per } \mathrm{kg})
$$

Results are shown in table 3, which could be compared to the natural background $(\approx 2 \mathrm{mSv} / \mathrm{y})$. It should be emphasized that results obtained from eqn. 3 are lower limits estimative since it was not considered there activities from the $U$ daughters.

Bones: One should be much more concerned with the results for U-accumulation in bone, since there are now evidences that through prolonged ingestion Uranium is accumulated and distributed in both bone and bone marrow as experimentally demonstrated elsewhere [18], also indicating that doses delivered to the bone stem cells (in the bone marrow) are intense enough as to induce neoplasia in individuals submitted to chronic ingestion of uranium, after a prolonged period of exposition.

It was estimated, in the present case study, that bones of Caetité city residents are annually exposed to internal effective doses two to three orders of magnitude higher than the natural background (Table 3). It is worth to recall that bones are the organ storing about $80 \%$ of the whole Uranium incorporation.

Kidneys and liver: The internal effective doses in kidneys and liver are very high too, but our calculations revealed an aggravating circumstance, in the sense that Uranium concentrations in these organs saturate at ages of 10 and 20 years, respectively (all results shown in tables 1 to 3 refer to 60 years old residents). This is of great concern too because, in this case, severe radiological burdens would be inflicted to children and young adults.

Also quite harmful, particularly for the youngest residents of Caetité, is the nephrotoxicity of Uranium and its compounds as uranyl salts - see e.g. the summary document ATSDR [21]. A

\begin{tabular}{|c|c|c|c|}
\hline \multicolumn{4}{|c|}{ Table 3: Effective doses (per year, per kg-organ) - this work. } \\
\hline Organs & $\mathbf{U}_{\text {conc }}[\mathbf{p p m}-\mathbf{U}]^{(1)}$ & Effective $\mathbf{a}$-dose $^{(2)}$ & $\mathbf{E}_{\mathbf{a}} / \mathbf{E}_{\text {nat }}{ }^{(3)}$ \\
\hline skeleton & $0.9-5.4$ & $4-23$ & $2000-11500$ \\
\hline kidneys & $0.4-2.2$ & $1.7-9$ & $850-4500$ \\
\hline liver & $0.2-1.0$ & $0.8-4.2$ & $400-2100$ \\
\hline blood & $(1.3-9) \times 10^{-3}$ & $(5.5-38) \times 10^{-3}$ & $3-19$ \\
\hline
\end{tabular}

${ }^{(1)} \mathrm{U}_{\text {conc }}[\mathrm{ppm}-\mathrm{U}]=T_{c}$. A (Eqn. 1); ${ }^{(2)} \mathrm{E}_{\mathrm{a}}(\mathrm{Sv} / \mathrm{y} \cdot \mathrm{kg})$, Eqn. $3 ;{ }^{\left({ }^{3}\right)} \mathrm{E}_{\text {nat }} \approx 2 \mathrm{mSv} / \mathrm{y}$ is the natural background. compilation of Uranium burdens in kidney published by Chen, et al. [22] shows that after 25 years of chronic ingestion, the Uranium burden in kidneys reaches its final equilibrium for all age groups.

Blood: This organ presented the smallest Uranium concentrations, but in relative terms its internal effective doses are up to one order of magnitude higher than the natural background (Table 3). Moreover, and much more alarming, the calculations indicate that Uranium transfer to blood saturate quite swiftly at ages between 2 and 3 years (Figure 2).

Although these predictions could be of use for dose evaluation, it is important to point out that Uranium concentration in blood and soft tissues is not well described in literature. The majority of data feeding ICRP models were obtained from acute injection studies, and because of this, results from ICRP model calculations for chronic regime must be analyzed and used cum grano salis. The present calculations, for instance, assume that flow parameters and organ's transfer coefficients are constant during a 60 years life span, and that they do not depend on the physiological tolerance to long exposures.

\section{Conclusion}

Estimates of $\mathrm{U}$ ingestion by residents of Caetité are three orders of magnitude higher than worldwide average ingestion, a circumstance strongly suggesting that food and water from this Uranium-rich region would exhibit high levels of contamination.

Uranium transfer coefficients of bones and kidneys saturate for the estimated ingestion range $(2-12 \mathrm{mg}-\mathrm{U} / \mathrm{d})$, a strong indication that Uranium ingestion rates by Caetité residents are very high.

Effective internal doses are from one (in blood) to three (in skeleton and kidneys) orders of magnitude higher than the background doses. Such a circumstance could lead to serious health problems as neoplasia.

As a byproduct, this work could subside further studies toward the identification of the driving factors in environmental pollution, associated with possible risks to the public health.

\section{Acknowledgement}

The authors acknowledge the Brazilian Agencies FAPESP and $\mathrm{CNPq}$ for partially supporting this work.

\section{References}

1. Fernandes HM, Gomiero LA, Peres V, Franklin MR, Simões Filho FF. Critical analysis of the waste management performance of two uranium production units in Brazil-part II: Caetite production Center. J Environ Manage. 2008; 88: 914-925.

PubMed: https://www.ncbi.nlm.nih.gov/pubmed/17619076 
2. Prado GR, Arruda-Neto JD, Sarkis JE, Geraldo LP, Müller RM, et al. Evaluation of Uranium incorporation from contaminated áreas using teeth as bioindicators - a case study. Radiation Protection and Dosimetry. 2008; 130: 249-252.

PubMed: https://www.ncbi.nlm.nih.gov/pubmed/18192333

3. Tsuji LJ, Nieboer E, Karagatzides JD, Kozlovic DR. Elevated dentine lead levels in adult teeth of first nation people from an isolated region of northern Ontario, Canada. Bulletin of Environmental Contamination and Toxicology. 1997; 59; 854-860.

PubMed: https://www.ncbi.nlm.nih.gov/pubmed/9400653

4. Garcia F, Mesa J, Arruda-Neto JDT, Helene O, Vanin V, et al. The STATFLUX code: a statistical method for calculation of flow and set of parameters, based on the Multiple-Compartment Biokinetical Model. Computer Physics Communications. 2007; 176: 347-361.

5. IAEA Safety Standards Series No. GSG-9 (2018-a), ISBN 978-92-0102418-3.

6. IAEA Safety Standards Series No. GSG-10 (2018-b), ISBN 978-92-0102518-0.

7. Austin AL, Lord BI, Ellender M, Haines JW \& Harrison JD. Microdosimetry for leukaemogenic target cells for bone-incorporated alpha-emitting radionuclides. Radiation Protection Dosimetry. 1998; 79: 391-394.

8. Austin AL, Ellender M, Haines JW, Harrison JD, Lord BI. Temporal change in microdosimetry to bone marrow and stromal progenitor cells from alpha-particle-emitting radionuclides incorporated in bone. Radiat Res. 1999; 152: S38-S42.

PubMed: https://www.ncbi.nlm.nih.gov/pubmed/10564934

9. Hei TK. Response of Biological Systems to Low Doses of Ionizing Radiation. Health Phys. 2016; 110: 281-282.

PubMed: https://www.ncbi.nlm.nih.gov/pubmed/26808883

10. Birchall A, James AC. A microcomputer algorithm for solving first-order compartmental models involving recycling. Health Phys. 1989; 56: 857868.

PubMed: https://www.ncbi.nlm.nih.gov/pubmed/2722508

11. Press WH, Teukolsky SA, Vettrling WT, Flannery BP. Numerical Recipes in FORTRAN, "The Art of Scientific Computing". (2nd ed.). Cambridge: Cambridge University Press. 1992.

12. ICRP-International Commission on Radiological Protection. Publication
69. Age-dependent Doses to Members of the public from intake of radionuclides. Part 3, Ingestion Dose Coefficients: Annals of the ICRP. 1995; 25

13. Garcia F, Barioni A, Arruda-Neto JD, Deppman A, Milian F, et al. Uranium levels in the diet of São Paulo City residents. 2006; Environ Int. 32: 697-703.

PubMed: https://www.ncbi.nlm.nih.gov/pubmed/16626805

14. Steenhout A, Pourtois M. Lead accumulation in teeth as a function of age with different exposures. $\mathrm{Br} \mathrm{J}$ Ind Med. 1981; 38: 297-303. PubMed: https://www.ncbi.nlm.nih.gov/pubmed/7272245

15. Leggett RW. An age-specific kinetic model of lead metabolism in humans. Environ Health Perspect. 1993; 101: 598-616. PubMed: https://www.ncbi.nlm.nih.gov/pubmed/8143593

16. UNSCEAR (United Nations Scientific Committee on the Effects of Atomics Radiations). Report to General Assembly, 93-156. New York: United Nations. 2000

17. Arruda-Neto JDT, Tavares MV, Filadelfo M. Concentrations of uranium in animal feed supplements: measurements and dose estimates. J Radioa Nuclear Chem. 1997; 221: 97-104.

18. Arruda-Neto JD, Guevara MV, Nogueira GP, Saiki M, Cestari AC, Longterm accumulation of uranium in bones of Wistar rats as function of intake dosages. Radiat Prot Dosimetry. 2004b: 112: 385-393. PubMed: https://www.ncbi.nlm.nih.gov/pubmed/15466919

19. Arruda-Neto JD, Manso Guevara MV, Nogueira GP, Taricano ID, Saiki $M$, et al. Long-term accumulation and microdistribution of uranium in bone and marrow of Beagle dogs. Int J Radiat Biol. 2004a; 80: 565575.

PubMed: https://www.ncbi.nlm.nih.gov/pubmed/15370968

20. Singh NP, Wrenn ME. Is the Beagle dog an appropriate experimental animal for extrapolating data to humans on organ distribution patterns of U, Th, and Pu? Health Phys. 1989; 57: 91-96.

PubMed: https://www.ncbi.nlm.nih.gov/pubmed/2606709

21. ATSDR-Agency for Toxic Substances and Disease Registry (ATSDR). Toxicological profile for uranium. Atlanta: ATSDR. 1999.

22. Chen J, Meyerhof DP, Tracy BL. Model results of kidney burdens from uranium intakes. Health Phys. 2004; 86: 03-11.

PubMed: https://www.ncbi.nlm.nih.gov/pubmed/14695003 